\title{
Description of socioeconomic and demographic profile of young women vulnerable to infection by human papillomavirus and risk behavior in a school in Rio de Janeiro
}

\author{
Maria Cristina de Melo Pessanha Carvalho ${ }^{1,2^{*}}$, Ana Beatriz Azevedo Queiroz ${ }^{3}$, \\ Maria Aparecida Vasconcelos Moura ${ }^{3}$ \\ ${ }^{1}$ Researcher Center Women’s Health, School of Nursing Anna Nery, Federal University of Rio de Janeiro, Rio de Janeiro, Brasil; \\ *Corresponding Author: mcrismelo4@hotmail.com \\ ${ }^{2}$ Federal Hospital Ipanema, Rio de Janeiro, Brasil \\ ${ }^{3}$ Department of Maternal-Child Nursing, Researcher Center Women’s Health, School of Nursing Anna Nery, Federal University of \\ Rio de Janeiro, Rio de Janeiro, Brasil
}

Received 24 August 2013; revised 25 September 2013; accepted 8 October 2013

Copyright (C) 2013 Maria Cristina de Melo Pessanha Carvalho et al. This is an open access article distributed under the Creative Commons Attribution License, which permits unrestricted use, distribution, and reproduction in any medium, provided the original work is properly cited.

\section{ABSTRACT}

Background: HPV is one of the main sexually transmitted diseases, especially among the female population. This is an important etiologic agent for the development of cervical intraepithelial lesions and cervical cancer. It is considered a public health problem, since young women are the most vulnerable group to this virus. Therefore, it is important that the socioeconomic and demographic profile of these women and their risk behaviors are known, so that it is possible to contribute in reducing infection occurrences in the studied population. Objectives: To describe the socioeconomic and demographic characteristics and investigate the behavioral sexual-affective aspects of risk of adolescents and young students from Rio de Janeiro/Brazil when tackling HPV infection. Methods: A group composed by 128 individuals susceptible to HPV—classified as adolescent women and young women who are students at a high school in one unity of the municipality of Rio de Janeiro. The studied period was from May to November. A quantitative descriptive approach was used, in which data were highlighted in variables, divided into economic, demographic and behavioral characteristics. Data were entered into an Excel spreadsheet and organized by descriptive statistics performed by simple frequency (\%). Results: The age range of the young women who have the possibility of being infected with HPV was from 15 to 25 . The focused family income among these young women was up to 2 minimum wages. The risk behavior detected in $37.5 \%$ of adolescent women and in $43.8 \%$ of young women is that these women never used condoms in sexual intercourse. Conclusion: The research showed that the studied women are vulnerable due to risk behavior practices that may lead to the virus acquisition. More focuses on educational actions of preventive measures regarding HPV infection should be emphasized, favoring a lower incidence of human papillomavirus infection and cervical cancer.

Keywords: Women's Health; HPV; Risk-Taking

\section{INTRODUCTION}

Human papillomavirus (HPV) is a virus that infects the epithelial cells of the skin and mucosa, being one of the most common sexually transmitted diseases in the female population. This infection occurs preferentially in the genital organs, as the vulva, vagina, uterine cervix, penis and perianal areas and oropharynx. Thanks to the molecular biology techniques, the association between HPV and cancer has been increasingly investigated. There are over 100 viral types and subtypes, and some of these viruses may cause lesions, which, if not treated, may evolve to cancer [1]. HPV is grouped in viral sub- 
types of low-risk $(6,11,42,43$ and 44$)$ and high-risk (16, 18, 31, 33, 34, 35, 39, 45, 46, 51, 52, 56, 58, 59, 66, 68, $70)$, thereby establishing the relationship between persistent infection by HPV with some viral types and cervical cancer. Thus, in $95 \%$ of cases, HPV is associated to cervical cancer [2]. The highest prevalence of this infection is among adolescent and young women, from 15 to 25, which causes this group to be considered as the one of higher vulnerability to HPV [3]. Early initiation of sexual activity and multiple partners are some behavioral factors that lead this population segment to a greater susceptibility [3]. Adding to that, there are the environmental and individual factors, which, together with HPV virus, modulate the risk of transition from infection to malignancies, including genetic susceptibility, immune and nutritional condition, tobacco use, multiparity, infections by other sexually transmitted agents-such as HIV, chlamydia trachomatis and herpes type 2 [4].

However, studies have reported that there are still barriers that prevent young people to adopt effective preventive measures against this infection, since big challenges are found in the difficulty of the adolescent to understand himself as vulnerable and make decisions and act in order to face this infection and other sexually transmitted diseases [5]. In this scenario, it is necessary to know the characteristics of this populational group, indicating their behaviors and attitudes that make them vulnerable to the infection [6]. Studies on this topic become relevant when building strategies of assistance that may reduce the chain of transmission of HPV and consequently morbimortality through precursor lesions and cervical cancer. From these arguments, this study aims to describe the socioeconomic demographical characteristics and to investigate the behavioral sexual-affective aspects of risk in adolescents and young students from Rio de Janeiro/Brazil against HPV infection.

\section{METHODS}

This is a descriptive study with quantitative analysis, held in a high school (public school) of the municipality of Rio de Janeiro. Such study had, as participants, 128 young women enrolled in the referred school, aged between 15 and 25 years. The sample was divided in two groups: adolescent women (AW) and young women (YW). The first group was composed by adolescent women in the age group from 15 from 19 and the second group by young women from 20 to 25 . This division was partially grounded in the chronological limits of adolescence, as defined by World Health Organization (WHO), which are from 10 to 19 . For young people, this limits are from 20 to 24, which division is used mainly for statistical and political purposes. As inclusion criteria, this study had adolescents and young people who were not infected by HPV, and had as exclusion criteria ages be- low 15 and above 25. To collect data, we used a form with the purpose of tracing the socioeconomic and demographic profile of the sample and raising the sexualaffective behaviors that may lead these young women to contract HPV. The data was divided in two blocks of variables: identification data in which were highlighted variables such as age, ethnicity, education, marital status, family income; the second block dealt with the characteristics related to risk behavior variables: beginning of sexual activity, number of partners in the last year, condom use and type of sexual activity. The sampling was determined by non-probability sampling technique by convenience, after the confirmation that the studied ones did not have HPV. At school the students were subjected to individual interviews between the months of May and November of 2012, to respond to the form in private local to ensure the privacy of the individuals. Data was entered into an Excel spreadsheet and organized by descriptive statistics performed by simple frequency (\%), and were subsequently inserted in tables for easy visualization of the results. The analysis was performed by percent calculation and organization by variables of each group. The study was submitted to the Comitê de Ética da Escola de Enfermagem Anna Nery (Ethics Committee of Anna Nery Nursing School)/Hospital-Escola São Francisco de Assis (Teaching Hospital São Francisco de Assis)/Universidade Federal do Rio de Janeiro (Federal University of Rio de Janeiro), being approved by record number 030/2011. The recommendations of Resolution number 196/96 of the Conselho Nacional de Saúde (National Health Council) Brazilian document that comprises standards and rules for the development of human research. Also, as recommended, the data was collected only after signing the Free and Clarified Consent Form and the Assent Form, signed by the responsible for students under 18.

\section{RESULTS}

The study included 128 subjects: 64 adolescent women and 64 young women. The age between 20 and 22 was most representative among both groups. The white group predominated among women vulnerable to HPV, represented by $53 \%$ of adolescent women. As for education level, only $25.1 \%$ of adolescent women and $18.6 \%$ of young women remained in high school, with a reduction in the number of women enrolled in the last year. In terms of marital status, there was a significant number of bachelor adolescent women with partner, represented by $56.25 \%$ - being him a boyfriend or a casual partner. However, $46.8 \%$ of young women are married, and often it is not an officially legal marriage, but guided by the choice of living in a consensual union with the partner. In contrast, $53.1 \%$ of respondents said they did not have a partner at the time of the interview. In this study, the 
variable family income predominated among adolescent women between 3 and 4 minimum wages. This fact was different among young women with $43.7 \%$ of them with familiar income up to 2 minimum wages. As for characteristics related to sexual-affective behavior, Table 1 shows that $31.25 \%$ of adolescent women and $37.5 \%$ of young women had between 4 and 5 partners in the last year. On the issue of condom use, only $15.6 \%$ of adolescent women and $9.3 \%$ of young women assert they always use a condom during sexual intercourse. The type of sexual intercourse preferred by adolescent women was vaginal sex and oral/vaginal sex was preferred by $31.25 \%$ of young women. In the variable beginning of sexual activity, it was observed that the age group between 14 and 17 was predominant in both groups$43.7 \%$ in the adolescent women and $37.5 \%$ in the young women.

Table 1. Risk behavioral characteristics in young women vulnerable to infection by human papillomavirus.

\begin{tabular}{|c|c|c|c|c|}
\hline \multirow[t]{2}{*}{ Variable } & \multicolumn{2}{|c|}{ AW } & \multicolumn{2}{|c|}{ YW } \\
\hline & $\mathrm{n}$ & $\%$ & $\mathrm{n}$ & $\%$ \\
\hline \multicolumn{5}{|c|}{ Number of partners (last year) } \\
\hline 0 - 1 partner & 24 & 37.8 & 10 & 15.6 \\
\hline 2 - 3 partner & 12 & 18.7 & 16 & 25.1 \\
\hline 4 - 5 partner & 20 & 31.2 & 24 & 37.5 \\
\hline Above 5 partners & 08 & 12.2 & 14 & 21.8 \\
\hline \multicolumn{5}{|l|}{ Condom usage } \\
\hline Only in the first relation & 16 & 25.1 & 12 & 18.7 \\
\hline Always & 10 & 15.6 & 06 & 9.30 \\
\hline Sometimes & 14 & 21.8 & 18 & 28.2 \\
\hline Never & 24 & 37.5 & 24 & 43.8 \\
\hline \multicolumn{5}{|l|}{ Type of performed sex } \\
\hline Vaginal sex & 11 & 34.4 & 06 & 18.7 \\
\hline Oral/vaginal sex & 04 & 12.5 & 10 & 31.2 \\
\hline Anal/vaginal sex & 06 & 18.8 & 05 & 15.6 \\
\hline Oral sex & 03 & 9.30 & 02 & 6.25 \\
\hline Anal sex & 08 & 25.0 & 09 & 28.2 \\
\hline \multicolumn{5}{|l|}{ Início de vida sexual } \\
\hline 9 - 13 years old & 12 & 18.7 & 10 & 15.6 \\
\hline 14 - 17 years old & 28 & 43.7 & 24 & 37.5 \\
\hline 18 - 21 years old & 16 & 25.1 & 20 & 31.3 \\
\hline 22 - 25 years old & 8 & 12.5 & 10 & 15.6 \\
\hline
\end{tabular}

AW: Adolescent women; YW: Young women.

\section{DISCUSSION}

Given the description of the young women attending a school unit that have the possibility of being infected with HPV, Table 2 illustrates a predominance of ages between 17 and 22. There is a decline from 23 years old and above. This age group is more prone to be infected by the virus because studies show that one of the major risk factors is age-and there is a prevalence among young women up to 24 years old [7,8]. It is noteworthy that this prevalence peak among these women is due to a higher level of switching of partners and early sexual initiation [9]. HPV infection affects young women at the start of sexual activity, being a transient phenomenonfor that, it declines spontaneously in most cases [10].

Table 2. Socioeconomic and demographic characteristics of young women vulnerable to infection by human papillomavirus.

\begin{tabular}{cccccc}
\hline Variables & AW & & \multicolumn{2}{c}{ YW } \\
\hline & n & $\%$ & n & $\%$
\end{tabular}

Age group

$\begin{array}{lll}15-16 & 15 & 46.8 \\ 17-19 & 17 & 53.2\end{array}$

$20-22$

$23-24$

$19 \quad 59.4$

Ethnic group

$$
\text { Black }
$$

Medium brown

White

Brazilian natives

Education level

$\begin{array}{ccccc}\text { High school (first year) } & 13 & 40.6 & 14 & 43.7 \\ \text { High school (second year) } & 11 & 34.3 & 12 & 37.5 \\ \text { High school (third year) } & 08 & 25.1 & 06 & 18.8 \\ \quad \text { Marital status } & & & & \\ \text { Single without partner } & 24 & 37.5 & 10 & 15.6 \\ \text { Single with partner } & 36 & 56.2 & 24 & 37.6 \\ \text { Married/consensual union } & 04 & 6.25 & 30 & 46.8 \\ \quad \text { Family income } & & & & \\ \text { Up to 2 MW } & 26 & 40.6 & 28 & 43.7 \\ \text { Between 3 and 4 MW } & 32 & 50.0 & 24 & 37.6 \\ \quad \text { Above } 5 \text { MW } & 06 & 9.40 & 12 & 18.7\end{array}$

AW: Adolescent Woman; YW: Young Woman; MW: Minimum Wage. 
As for ethnicity, scarce literature mentions the association of ethnicity/color with a predisposition to HPV infection. The present study indicates that white women predominated among adolescents; between young women the medium brown had greater prominence, with a total of $46 \%$. That confirms the study by Pereyra et al., in which it is referred that more than half of the cases of cervical cancer due to infection by HPV is constituted by nonwhite women [11]. It was observed that the black ethnicity was associated with the prevalence and incidence of HPV carcinogenic infection, but it was not a significant risk factor for infection [12]. However, another study indicates that the increased risk of HPV infection in black women is attributed not to genetics, but to socioeconomic characteristic. [13].

In terms of education level, the dropping-out of young women before completing high school was emphasized. Many of them stop attending high school. Many of these young women are confronted with events in their lives that prevent them from continuing their studies-for example, inclusion in the labor market or early pregnancy. It is noticed that the studied individuals are vulnerable when there is a hindrance to improve the knowledge of a cognitive mechanism when facing situations that may favor the acquisition of sexually transmitted diseases. Still the sub-information is also considered as one of the main barriers to be overcome in the control of sexually transmitted diseases, especially when it comes to the human papillomavirus, because the lack of education influences the risk perception; and the non-providing of attitudes to prevent HPV suggests the association of lower education with higher prevalence of HPV infection [14,15].

With regard to the marital status of these young women, more than half of the adolescents are unmarried with partner, and only $6.25 \%$ are married or are living in a consensual union. This fact illustrates that these women may be vulnerable to HPV virus, independently of appropriate sexual behavior or sexual risk behavior. Some studies show that having a steady partner establishes a condition of defenselessness to the virus since condom use is discarded after the relationship becomes stable [16]. This fact may occur by reason of trust or even by submission to the partner when it comes to discussing the continuity of usage of condom in sexual intercourse [17].

Regarding family income of the analyzed vulnerable to HPV women, it is clear that incomes are still low among the subjects of study and that few women live with incomes superior to two MW. The results show that some adolescents have a higher income than the other group by reason of living with their parents and/or family, by whom they are still supported. However, in what refers to non-adolescent women, many of them no longer live with their families and are now inserted in the labor market, being responsible for their own sustenance or must support their families, and that interferes in the learning process. It is assumed that this is a vulnerable population when the low incomes lead to social inequalities, hindering the access to necessary information to prevent sexually transmitted diseases [18].

Several studies show that the number of partners among women is a relevant factor because de multiplicity of partners is a major risk factor for acquiring HPV infection $[13,19]$. As for the present study there is a variety of partners especially among young women. Thus, the studied women with more than three partners are submitted to a vulnerable situation when there is a frequent exchange of partners, allowing unsafe sexual behavior and consequently a major chance of contracting sexually transmitted diseases, especially when condom is not used. The increased number of sexual partners during the life of the studied women also favors different sexual practices that may lead to a greater possibility of HPV infection. Age difference between the couple may also increase the risk [20]. However, other than literature indicates, the survey also illustrated that $37.8 \%$ of adolescents only had one partner in the last year. This fact may lead to the absence of protective measures, as it involves a long-term relationship and the adolescent stops using condoms.

Data suggests that the number of women who do not use condoms is still high, favoring a greater exposure to the human papilloma virus, because $37.5 \%$ of adolescents and $43.8 \%$ of young women said they never used condoms. This information is relevant when it is known that these women are in a situation of vulnerability to HPV, since they are exposed to beliefs, gender inequalities and are passive to the partner, becoming dependent on him to condom usage. The use of condoms among women is a subject that is related to sexual-affective relationship, because the type of relationship that young people establish — of great affection or only casual sexis a contributing factor to the decision to use condom or not [17].

There is a difficulty among the studied women to use condom when they are faced with negotiating about con dom usage with their partners, either for fear of losing the partner or insecurity in the relationship. Thus, it is clear that condom usage is linked to intimacy between partners. Some reasons are associated with this behavior, like: only having sex with a partner that the woman trusts, disliking condom usage because it would diminish pleasure in intercourse or because the studied woman thinks she will not have any disease [21].

The age group that prevailed in this research about sexual initiation was between 14 and 17, a result that agrees with the study by Martins et al., wherein from a total of 8649 women, $74 \%$ reported that the first inter- 
course occurred between the ages of 14 and 20 [22]. This is an important fact when the early onset of sexual activeity is one of the factors for contracting HPV. This is due to the fact that young cells are more receptive to infection by human papillomavirus and to the fragility of the uterine cervix in the initiation of sexual life [23,24]. Adding to that there is a relation between the early onset of sexual activity and an increased risk of infection with HPV due to the augmentation of time of exposure, leading to a larger risk of being infected with the virus [25].

In terms of sexual preferences among young women, even predominating the choice for vaginal sex, there was also a prominence for anal sex. The incidence of anal cancer associated to HPV among women has shown an increase of $40 \%$ in recent years [26]. This may be linked to socio-cultural factors that may be decisive in the behavior of these women, since family, education level and access to media and social networks are important sources of information and influence the behavior of these women, especially when it comes to sexual behaveior. Adding to that, there is the fact that the studied women are vulnerable, since during intercourse there is an exchange of sexual fluids, which directly relates to the transmission of various microorganisms, such as HPV, HIV and other STDs, depending on the performed sexual practice [27]. As for oral sex-also mentioned by young women-there is a significant evolution for squamous cell carcinoma in the oropharynx area, basis of the tongue and palatine tonsils, associated with HPV [28]. This condition can be worsened with modifiable risk factors for cancer such as smoking and alcohol consumption [29]. This situation determines the vulnerable condition of these women, finding themselves in a situation of defenselessness concerning the virus.

\section{CONCLUSION}

From the results, it was possible to identify that these young woman students that have the possibility of being infected with HPV are inserted into a profile of low socioeconomic conditions, especially when these women interrupt the cycle of learning, characterized by dropping out of school, which interferes in the seizure of information and in the understanding of the importance of preventive measures. The results showed that high school students are in a situation of vulnerability due to their risk behaviors, primarily by low adherence to condom usage, in addition to the multiplicity of partners. It can be seen that according to the profile of the socioeconomic and demographic level and also of some risk behaviors, there are important factors that may lead to the acquisition of HPV. The development of goals for educational actions to improve the awareness of young women population-so they will have prevention attitudes and safe sexual behaviors in sexual and affective relationships- must be encouraged. Health professionals, specially nurses, have an important role in reducing HPV infection, with procedures that identify risks, emphasizing appropriate prevention conducts.

\section{REFERENCES}

[1] Santos, J.C., Cezar, M.R.S., Lisboa, M.R. and Moura, M.M.F. (2013) Ocorrência de papilomavírus humano na cérvice uterina de mulheres da região ocidental da Amazônia Brasileira. Acta Amazônica, 43, 185-190. http://dx.doi.org/10.1590/S0044-59672013000200008

[2] Munoz, N., Bosch, F.X., de Sanjose, S., Herrero, R., Castellsague, X., Shah, K.V., et al. (2003) Epidemiologic classification of human papillomavirus types associated with cervical cancer. New England Journal of Médicine, 348, 518-527. http://dx.doi.org/10.1056/NEJMoa021641

[3] Fernandes, J.V., Meissner, R.V., de Carvalho, M.G., Fernades, T.A., de Azevedo, P.R. and Villa, L.L (2009) Prevalence of HPV infection by cervical cytologic status in Brazil. International Journal of Gynecology \& Obstetrics, 105, 21-24. http://dx.doi.org/10.1016/j.ijgo.2008.12.004

[4] Schiffmann, M., Castle, P.E., Jeronimo, J., Rodriguez, A. C. and Wacholder, S. (2007) Human papillomavirus and cervical cancer. Lancet, 370, 890-907. http://dx.doi.org/10.1016/S0140-6736(07)61416-0

[5] Beserra, E.P., Pinheiro, P.N.C., Alves, M.D.S. and Barroso, M.G.T. (2008) Adolescência e vulnerabilidade às doenças sexualmente transmissíveis: Uma pesquisa documental. DST-Jornal Brasileiro de Doenças Sexualmente Transmissiveis, 20, 32-35.

[6] Oliveira, D.C., Gomes, A.M.T., Pontes, A.P.M., Ribeiro, M.C.M. (2009) Conhecimentos e práticas de adolescentes acerca das DST/HIV/AIDS em duas escolas públicas municipais do Rio de Janeiro. Escola Anna Nery, 13, 833841.

http://dx.doi.org/10.1590/S1414-81452009000400020

[7] Eleutério, R.M.N., Oliveira, M.A.P.O., Jacynto, C.M.A., Junior, J.E. and Freitas, J.R. (2011) Identificação de DNAHPV em Adolescentes e Mulheres Jovens sem Coito Vaginal. DST-Jornal Brasileiro de Doenças Sexualmente Transmissiveis, 23, 66-68.

[8] Bosch, F.X., Lorincz, A., Muñoz, N., Meijer, C.J.L.M. and Shah, K.V. (2002) The causal relation between human papillomavirus and cervical cancer. Journal of Clinical Pathology, 55, 244-265. http://dx.doi.org/10.1136/jcp.55.4.244

[9] Rama, C.H., Roteli-Martins, C., Derchain, S.F.M., Longatto-Filho, A., Gontijo, R.C., Sarian, L.O.Z., Syrjanen, K. and Aldrighi, J.M. (2008) Prevalência do HPV em mulheres rastreadas para o câncer cervical. Revista de Saúde Pública, 42, 123-130. http://dx.doi.org/10.1590/S0034-89102008000100016

[10] Zampirolo, J.A., Merlin, J.C. and Menezes, M.E. (2007) Prevalência de HPV de baixo e alto risco pela técnica de biologia molecular (captura híbrida II) em Santa Catarina. RBAC, 39, 265-268.

[11] Marcolino, L.D., Polettini, J., Tristão, A.R., Marques, M. 
A.E., Candeias, J.M.G. and Vela, R.A.R. (2008) Coinfecção de chlamydia trachomatis e HPV em mulheres com condiloma acuminado. DST-Jornal Brasileiro de Doenças Sexualmente Transmissiveis, 20, 87-92.

[12] Oakeshott, P., Aghaizu, A., Fiona Reid, F., Howell-Jones, R., Hay, P.E., Sadiq, S.T., Lacey, C.J. and Beddows, S. and Soldan, K. (2012) Frequency and risk factors for prevalent, incident, and persistent genital carcinogenic human papillomavirus infection in sexually active women: Community based cohort study. British Medical Journal, 344, 1-10. http://dx.doi.org/10.1136/bmj.e4168

[13] Fredrizzi, E.N., Schlup, C.G., Menezes, M.E. and Ocampos, M. (2008) Infecção pelo papilomavírus humano (HPV) em mulheres de Florianópolis, Santa Catarina. DST-Jornal Brasileiro de Doenças Sexualmente Transmissiveis, 20, 73-79.

[14] Khan, M.J., Partridge, E.E., Wang, S.S. and Schifffman, M. (2005) Socioeconomic status and the risk of cervical intraepithelial neoplasia grade 3 among oncogenic human papillomavirus DNA-positive women with equivocal or mildly abnormal cytology. Cancer, 104, 61-70. http://dx.doi.org/10.1002/cncr.21129

[15] Moller, F.R., Silva, J.C. and Sá, A.C. (2003) Prevenção do HPV: Uma proposta de educação em saúde. CadernosCentro Universitário S. Camilo, 9, 59-66.

[16] Teixeira, A.M.F.B., Knauth, D.R., Fachel, J.M.G. and Leal, A.F. (2006) Adolescentes e o uso de preservativos: As escolhas dos jovens de três capitais brasileiras na iniciação e na última relação sexual. Cad Saúde Pública, 22, 1385-1396. http://dx.doi.org/10.1590/S0102-311X2006000700004

[17] Ribeiro, K.C.S., Silva, J. and Saldanha, A.A.W. (2008) Querer é poder? A ausência do uso de preservativos nos relatos de mulheres jovens. DST-Jornal Brasileiro de Doenças Sexualmente Transmissiveis, 23, 84-89.

[18] Aquino, E M.L., Heilborn, L.M., Knauth, D., Bozon, M., Almeida, M.C., Araújo, J., et al. (2002) Adolescência e reprodução no Brasil: A heterogeneidade dos perfis sociais. Cadernos de Saúde Pública, 19, S377-S388. http://dx.doi.org/10.1590/S0102-311X2003000800019

[19] Stofler, M.E.C.W., Nunes, R.D. and Scheneider, I.J.C. (2011) Avaliação de faores associados às lesões HPV induzidas do colo uterino. Arquivos Catarinenses de Medicina, 40, 84-89.

[20] Baseman, J.G. and Koutsky, L.A. (2005) The epidemiology of human papillomavirus infections. Journal of Clinical Virology, 32, S16-S24. http://dx.doi.org/10.1016/j.jcv.2004.12.008

[21] Oliveira, D.C., Gomes, A.M.T., Pontes, A.P.M. and Ri- beiro, M.C.M. (2009) Conhecimentos e práticas de adolescentes acerca das DST? HIV? AIDS em duas escolas públicas municipais do rio de Janeiro. Escola Anna Nery Revista de Enfermagem, 13, 833-841. http://dx.doi.org/10.1590/S1414-81452009000400020

[22] Roteli-Martins, C.M., Longatto Filho, A., Hammes, L.S., Derchain, S.F.M., Naud, P., Matos, J.C., et al. (2007) Associação entre idade ao início da atividade sexual e subseqüente infecção por papilomavírus humano: Resultados de um programa de rastreamento brasileiro. Revista Brasileira de Ginecologia e Obstetrícia, 29, 580-587. http://dx.doi.org/10.1590/S0100-72032007001100006

[23] Moscicki, A.B. (2007) HPV infections in adolescents. Disease Markers, 23, 229-234. http://dx.doi.org/10.1155/2007/136906

[24] Pinto, D.S., Fuzzi, H.T. and Quaresma, J.A.S. (2011) Prevalência de infecção genital pelo HPV em populações urbana e rural da Amazônia Oriental Brasileira. Cadernos de Saúde Pública, 27, 769-778. http://dx.doi.org/10.1590/S0102-311X2011000400016

[25] Naud, P., Matos, J., Hammes, L., Stuckzynski, J., Brouwers, K., Magno, V., et al. (2006) Factors predicting intermediate endpoins of cervical cancer and exposure to human papillomavirus (HPV) infections in young women screened as pontential targets for propylatic HPV vaccination in south of Brazil. European Journal of Obstetrics \& Gynecology and Reproductive Biology, 124, 110-118. http://dx.doi.org/10.1016/j.ejogrb.2005.02.001

[26] Pimenta, A.V., Cândido, E.B., Lima, R.A., Filho, R.M.P., Capobiango, A., Nunes, T.A., et al. (2011) Importância da infecção anal pelo HPV em Mulheres. Femina, 39, 111116.

[27] Risvi, N. and Luby, S. (2004)Vaginal discharge: Perceptions and health seeking behavior among Nepalese Women. Journal Pakistan Medical Association, 54, 620-624.

[28] Heck, J.E., Berthiller. J., Vaccarella, S., Winn, D.M., Smith, E.M., Shan'gina, O. et al. (2010) Sexual behaviours and the risk of head and neck cancers: A pooled analysis in the International Head and Neck Cancer Epidemiology (INHANCE) consortium. International Journal of Epidemiology, 39, 166-181. http://dx.doi.org/10.1093/ije/dyp350

[29] Castro-Silva, I.I., Coutinho, L.A.C.R., Júnior, J.A.S., Pires, A.R.C. and Bastos, O.M.P. (2012) Percepção de Vulnerabilidade ao HPV e Câncer de Cabeça e Pescoço: Comportamentos Sexuais e de Risco em Jovens de Niterói, RJ. DST-Jornal Brasileiro de Doenças Sexualmente Transmissiveis, 24, 85-92. 